\title{
Pedological characteristics of soils in the watersheds of Oueds Nekôr and Ghiss (Central Rif; Morocco)
}

\author{
Soukaina Ed Dakiri ${ }^{1}{ }^{*}$, Hatim Faiz ${ }^{1}$, Jaouad Ouldchaib ${ }^{1}$, Said El Moussaoui ${ }^{1}$, Hajar El Talibi ${ }^{1}$, Hinde Cherkaoui Dekkaki ${ }^{1}$, \\ Taoufik Mourabit ${ }^{1}$, Saida Bouzid $^{2}$, Brahim Damnati $^{2}$, and Issam Etebaai ${ }^{1}$ \\ ${ }^{1}$ Laboratory of Research and Development in Engineering Sciences, Faculty of Science and Technology of Al Hoceima, Abdelmalek \\ Essaadi University, Tetouan, Morocco. \\ ${ }^{2}$ Environment, Oceanology and Natural Resources Laboratory, Faculty of Science and Technology of Tangier, Abdelmalek Essaadi \\ University, Tetouan, Morocco.
}

\begin{abstract}
The objective of this work is the pedological characterization of soils in the watersheds of Oueds Nekôr and Ghiss. Several profiles were identified and sampled for Physico-chemical and sedimentological analyses (color index, magnetic susceptibility, $\mathrm{pH}$, granulometry, water content, organic matter, and carbonates). The watersheds in question are roughly characterized by a soft and diversified lithology, a sparse vegetation cover, and a semi-arid Mediterranean climate. The soils in the Oued Nekôr watershed are of the silty type $(>50 \%)$, not very developed and relatively well-drained, and become well-drained stony in the steep and eroded areas. Soil $\mathrm{pH}$ varies between 7 and 8 , reflecting low alkaline to alkaline soils. In the Oued Ghiss watershed, the sandstone-limestone or marl-schist soils are poorly differentiated in the steep slopes. The well-drained soils are gravelly, relatively alkaline, and show the beginning of rubefaction. Very locally on wooded flats, the soil profiles can become deep and well-differentiated due to colluvial accumulation. The dark brown eluvial A horizon is relatively rich in organic matter (3.6\%). The well individualized illuvial B horizon has strongly rubbed concretions and is richer in organic matter $(4.6 \%)$. The light beige $\mathrm{C}$ horizon corresponds to the strongly altered marl and limestone parent rock with low organic matter content (1.3\%) and very low magnetic susceptibility values.
\end{abstract}

\section{Introduction}

The growing importance of environmental issues is leading to a renewed interest in soil heritage. The numerous hazards to which soils are subjected weaken their structure and affect their physicochemical and biological properties [1]. Water erosion is the primary cause of soil degradation in Morocco [2]. According to the High Commission for Water and Forests and the Fight against Desertification (HCEFLCD) (1996) [3], water erosion affects about 23 million ha of Moroccan land. In addition to the socio-economic damage and flood risks that threaten populations and infrastructure [4], this phenomenon reduces the hydraulic capacity of dams [5]. The north of Morocco, and particularly some regions of the Rif, are highly exposed to water erosion and siltation of water reservoirs because of the climatic aggressiveness, the rugged terrain, the tremendous lithological sensitivity (marl, marl-limestone, etc.), and the demographic pressure that knows the northern region [6], [7], [8], [9], [10], [11], [12], [13], [14].

The pedological characterization constitutes a preponderant step in all management strategies and agrosylvo-pastoral restoration of such regions vulnerable to climatic contrasts and anthropic pressure [15]. The present work aims to characterize some pedological properties of some soil profiles collected in the watersheds of Oueds Nekôr and Ghiss.

\section{Study sites}

The study sites are located in the eastern part of the inner Rif in northeastern Morocco and are part of the Mediterranean coastal basins (Figure 1).

The Oued Nekôr watershed has an area of $773.43 \mathrm{~km}^{2}$ and a perimeter of $170 \mathrm{~km}$. It is limited to the north by the Mohamed Ben Abdelkrim Al Khattabi dam through which it flows into the full Al Hoceima and limited to the south by the watershed of Wadi Sebou and the west by the watershed of Wadi Ghiss, and that of Wadi Kert to the east. The Oued Ghiss watershed, located $25.5 \mathrm{~km}$ south of Al-Hoceima, has $586.66 \mathrm{~km}^{2}$ and a perimeter of 132.52 $\mathrm{km}$.

\section{Materials and methods}

Three soil profiles were collected in each watershed using the trenching method. Sampling was done every $5 \mathrm{~cm}$. Wet color indices were determined using the Munsell chart. Sieving was done by wet sieving under running water to separate the coarse fraction from the fine fraction. The separation of the silty fraction from the clay fraction was done by sedimentometry. The $\mathrm{pH}$ of the soil was determined by a palliasse $\mathrm{pH}$ meter in a suspension of soil in distilled water. Bound water, organic matter, and

\footnotetext{
* Corresponding author: soukainaeddakiri@gmail.com
} 
carbonate contents were determined by loss on ignition [16]. Magnetic susceptibility was measured directly with a portable susceptibility meter.

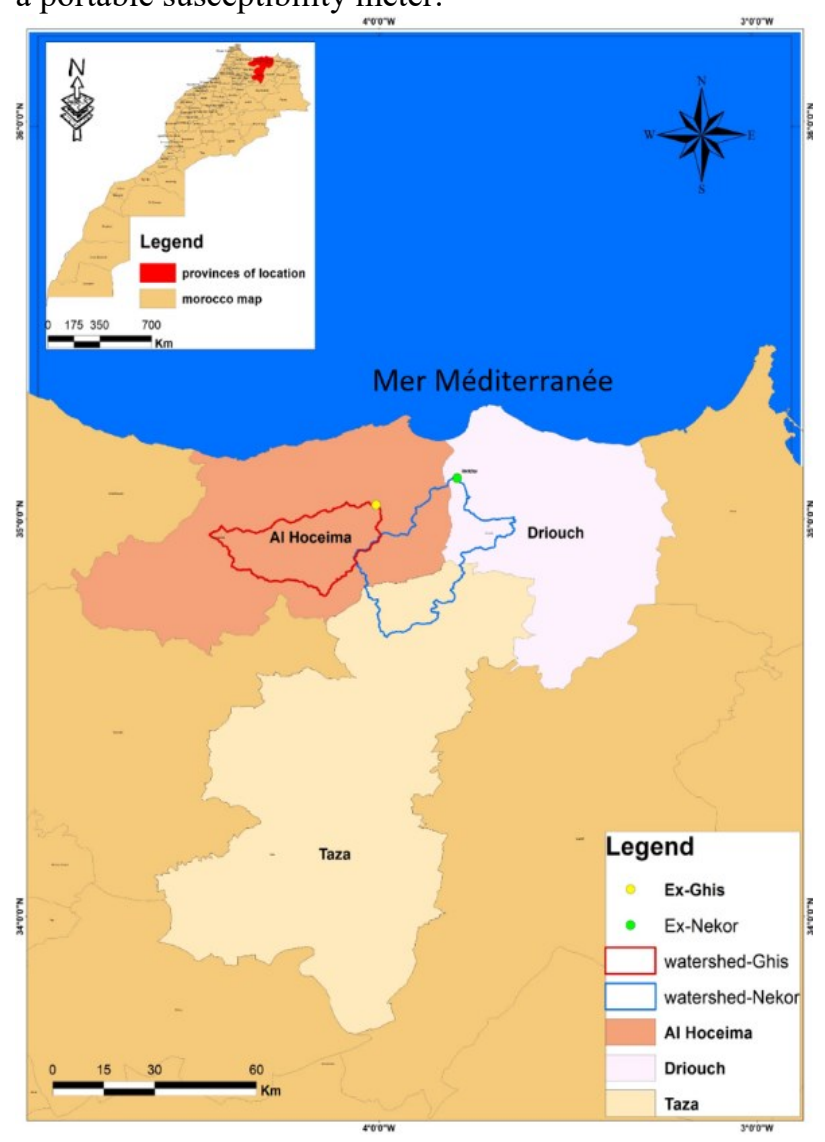

Fig. 1. The geographical location of Oueds Nekôr and Ghiss watersheds.

\section{Results and discussion}

\subsection{Soil profiles of the Oued Nekôr watershed}

Soil profile one was taken at the foot of a reforested almond tree slope on the left bank of Oued Nekôr. The other two profiles were taken from the fallow and sparse vegetation of the right bank.

The granulometric analysis reveals a predominance of the silty fraction for the different soil profiles studied in the Oued Nekôr watershed (Table 1). Profile $1(80 \mathrm{~cm}$ long) is rich in coarse fractions (gravel and sand) at the level of the $\mathrm{C}$ horizon $(35-75 \mathrm{~cm}$ deep). This fraction decreases significantly towards the surface in the B and A horizons, which become more affluent in silty fractions. The other two profiles $(50 \mathrm{~cm}$ depth) are richer in silt with reasonably high percentages of clay ( $15 \%$ on average) in profile two between 10 and $30 \mathrm{~cm}$ depth. This distribution reflects a well-drained soil that has not evolved much overall. However, the beginning of structuring is underlined, as in profile 2, which shows a median accumulation horizon rich in clayey-silty fraction.

The $\mathrm{pH}$ values show a soil that is not very alkaline at the surface $(\mathrm{pH}=7.8)$ and becomes alkaline with depth in profile $1(\mathrm{pH}=8.41)$. In profiles 2 and 3 , the alkaline soil is marked by a slight increase in $\mathrm{pH}$ with depth (Table 1). This evolution is mainly related to the low contribution of humic acids in connection with the low organic matter contents on the one hand and the precipitation of carbonates at the level of the soil horizons under semi-arid climate on the other hand.

Water content in the three profiles is very low and varies from $0.49 \%$ to $2.63 \%$. Their variation with depth is marked by a decrease in profile one and an increase in profiles 2 and 3 (Table 1). This evolution of bound water content generally follows the granulometric texture of the soil horizons.

The organic matter content is also low and varies from $1.15 \%$ to $2.25 \%$. Their evolution at depth is marked by their progressive decrease in profile one and their variability in profiles 2 and 3 (Table 1). This evolution is linked on the one hand to the predominance of coarse fractions that facilitate its rapid oxidation and, on the other hand, to the low contribution of organic matter sources of plant origin. The silty-clay fraction generally supports its distribution.

The carbonate content in profile 1 is higher than in profiles 2 and 3 . Their variation at depth is marked in profile one by their increase as they approach the bedrock. These low carbonate values reflect a rather aluminosilicate nature of the bedrock and are generally related to the coarse fraction.

The magnetic susceptibility shows relatively low values for the three profiles studied (from 0.05.10-3 to 2.3.10-3 SI on average). Its evolution is marked by its decrease in profile one and its increase in profiles 2 and 3 (Table 1). Supported mainly by the fine silt-clay fractions, the magnetic susceptibility is conditioned by the distribution of ferric elements.

\subsection{Soil profiles of the Oued Ghiss watershed}

The soil profiles 1 and 3 were taken at the level of the sparse matorral flanks of the left bank of Oued Ghiss. Profile 2 was taken at the foot of a reforested almond tree and wheat cultivated flank of the right bank.

The granulometric analysis shows the predominance of the sandy-silty fraction in the three soil profiles studied, followed by gravel. Clay content is low in all three profiles and always remains below $8 \%$ (Table 2 ). The evolution with depth is marked by the increase of gravel on the one hand and the decrease of the sandy-silty fraction on the other hand in profile 1 . While in profiles 2 and 3 , there is an overall decrease in coarse fractions (gravels and sands) and an increase in fine fractions (silt and clay) from the middle horizon towards the bedrock (Table 2). This distribution reflects a well-drained and not significantly evolved soil. The measured $\mathrm{pH}$ of the soils in the Oued Ghiss watershed ranges from 7.35 to 8.17 and reflects a low alkaline to alkaline soil. The same conditions of oxidation of organic matter and precipitation of carbonates govern the distribution of soil $\mathrm{pH}$ in the Oued Ghiss watershed. 
Table 1. Sedimentology and geochemistry of soil profiles of the Oued Nekôr watershed.

\begin{tabular}{|c|c|c|c|c|c|c|c|c|c|c|c|}
\hline Profile & $\begin{array}{c}\text { Depth } \\
\text { (cm) }\end{array}$ & $\begin{array}{c}\text { Munsell } \\
\text { color }\end{array}$ & $\begin{array}{c}\text { Gravel } \\
(\%)\end{array}$ & $\begin{array}{c}\text { Sand } \\
(\%)\end{array}$ & $\begin{array}{l}\text { Silt } \\
(\%)\end{array}$ & $\begin{array}{l}\text { Clay } \\
(\%)\end{array}$ & pH & $\begin{array}{l}\mathrm{H}_{2} \mathrm{O} \\
(\%)\end{array}$ & $\begin{array}{l}\text { OM } \\
(\%)\end{array}$ & $\begin{array}{c}\mathrm{CaCO}_{3} \\
(\%) \\
\end{array}$ & $\begin{array}{c}x \\
\left(10^{-3} \mathrm{SI}\right) \\
\end{array}$ \\
\hline \multirow{6}{*}{1} & $0-5$ & RYR 4/3 & 32,46 & 21,85 & 38,66 & 7,03 & 7,89 & 1,02 & 2,04 & 1,27 & 1,14 \\
\hline & $5-10$ & RYR 3/4 & 49,21 & 16,99 & 31,64 & 2,16 & 7,78 & 1,51 & 2,26 & 2,02 & 0,36 \\
\hline & $10-20$ & $5 \mathrm{YR} 4 / 4$ & 42,76 & 21,85 & 33,66 & 1,73 & 8,08 & 1,36 & 2,08 & 2,05 & 1,09 \\
\hline & $20-35$ & $2,5 \mathrm{YR} 4 / 4$ & 29,71 & 26,84 & 40,14 & 3,31 & 8,12 & 1,44 & 1,85 & 3,10 & 1,22 \\
\hline & $35-55$ & 7,5YR 8/2 & 60,72 & 24,93 & 13,21 & 1,14 & 8,33 & 0,73 & 1,16 & 6,01 & 0,06 \\
\hline & $55-75$ & $10 \mathrm{YR} 6 / 2$ & 74,13 & 18,75 & 6,53 & 0,59 & 8,41 & 0,49 & 1,03 & 5,72 & 0,08 \\
\hline \multirow{4}{*}{2} & $0-10$ & $10 \mathrm{R} 4 / 4$ & 21,66 & 26,80 & 45,79 & 5,75 & 8,02 & 1,77 & 2,10 & 1,48 & 1,54 \\
\hline & $10-20$ & $10 \mathrm{R} 4 / 3$ & 13,19 & 18,11 & 57,44 & 11,26 & 8,06 & 1,73 & 1,92 & 0,68 & 2,17 \\
\hline & $20-30$ & $10 \mathrm{R} 3 / 3$ & 19,45 & 15,51 & 46,48 & 18,56 & 8,07 & 2,43 & 1,96 & 0,01 & 2,33 \\
\hline & $30-50$ & $10 \mathrm{R} 3 / 3$ & 38,27 & 19,93 & 39,84 & 1,96 & 8,08 & 2,63 & 2,12 & 0,76 & 2,05 \\
\hline \multirow{4}{*}{3} & $0-10$ & $7,5 \mathrm{YR} 5 / 3$ & 46,89 & 32,91 & 19,24 & 0,97 & 8,22 & 0,64 & 1,45 & 0,37 & 0,70 \\
\hline & $10-20$ & $5 \mathrm{YR} 4 / 3$ & 22,86 & 29,11 & 44,53 & 3,50 & 8,32 & 1,78 & 1,72 & 0,45 & 1,66 \\
\hline & $20-30$ & $5 \mathrm{YR} 5 / 4$ & 16,79 & 28,30 & 51,00 & 3,91 & 8,39 & 1,48 & 2,20 & 1,07 & 1,01 \\
\hline & $30-50$ & $5 \mathrm{YR} 3 / 3$ & 14,18 & 27,10 & 54,47 & 4,25 & 8,64 & 2,18 & 1,99 & 0,89 & 1,25 \\
\hline
\end{tabular}

BW: Bound Water; OM: Organic matter; $\mathrm{CaCO}_{3}$ : Carbonate; $\mathcal{X}$ : magnetic susceptibility

Table 2. Sedimentology and geochemistry of soil profiles of the Oued Ghiss watershed.

\begin{tabular}{|c|c|c|c|c|c|c|c|c|c|c|c|}
\hline Profile & $\begin{array}{l}\text { Depth } \\
\text { (cm) }\end{array}$ & $\begin{array}{c}\text { Munsell } \\
\text { color }\end{array}$ & $\begin{array}{c}\text { Gravel } \\
(\%)\end{array}$ & $\begin{array}{c}\text { Sand } \\
(\%)\end{array}$ & $\begin{array}{l}\text { Silt } \\
(\%)\end{array}$ & $\begin{array}{l}\text { Clay } \\
(\%)\end{array}$ & pH & $\begin{array}{l}\text { BW } \\
(\%)\end{array}$ & $\begin{array}{l}\text { OM } \\
(\%)\end{array}$ & $\begin{array}{c}\mathrm{CaCO}_{3} \\
(\%)\end{array}$ & $\begin{array}{c}x \\
\left(10^{-3} \mathrm{SI}\right)\end{array}$ \\
\hline \multirow{4}{*}{1} & $0-10$ & $2,5 \mathrm{Y} 4 / 3$ & 7,01 & 53,58 & 34,19 & 5,21 & 8,03 & 0,52 & 1,47 & 0,59 & 0,41 \\
\hline & $10-20$ & $10 \mathrm{Y} 3 / 3$ & 5,90 & 63,11 & 28,00 & 2,99 & 8,11 & 0,27 & 1,36 & 0,41 & 0,46 \\
\hline & $20-40$ & $7,5 \mathrm{YR} 4 / 3$ & 26,36 & 45,04 & 26,10 & 2,51 & 7,35 & 0,74 & 1,46 & 0,56 & 0,27 \\
\hline & $40-50$ & 7,5YR 5/4 & 59,08 & 19,15 & 19,18 & 2,60 & 7,94 & 0,86 & 1,35 & 0,58 & 0,03 \\
\hline \multirow{7}{*}{2} & $0-10$ & $5 \mathrm{YR} 5 / 4$ & 20,19 & 26,45 & 45,32 & 8,04 & 7,91 & 0,90 & 2,42 & 1,74 & 0,86 \\
\hline & $10-20$ & $5 Y R 5 / 4$ & 22,95 & 22,66 & 46,28 & 8,11 & 7,86 & 0,97 & 2,93 & 1,86 & 0,60 \\
\hline & $20-40$ & $5 \mathrm{YR} 3 / 3$ & 11,42 & 44,60 & 36,68 & 7,30 & 8,01 & 1,06 & 3,13 & 0,98 & 0,93 \\
\hline & $40-60$ & $5 Y R 3 / 2$ & 41,48 & 29,86 & 26,68 & 1,97 & 7,95 & 0,02 & 3,92 & 0,56 & 0,87 \\
\hline & $60-80$ & $5 Y R 3 / 4$ & 19,09 & 52,16 & 26,34 & 2,41 & 7,9 & 1,22 & 1,81 & 0,21 & 0,54 \\
\hline & $80-100$ & $7,5 Y 5 / 3$ & 9,98 & 37,69 & 45,50 & 6,83 & 8,05 & 1,47 & 1,90 & 4,34 & 0,29 \\
\hline & $100-120$ & $10 \mathrm{YR} 8 / 3$ & 0,64 & 8,94 & 81,48 & 8,94 & 8,17 & 1,55 & 1,49 & 6,89 & 0,16 \\
\hline \multirow{4}{*}{3} & $0-20$ & $5 Y R 4 / 3$ & 32,39 & 28,99 & 33,22 & 5,41 & 8,00 & 0,42 & 2,54 & 0,42 & 0,47 \\
\hline & $20-40$ & $5 \mathrm{YR} 4 / 4$ & 33,85 & 40,68 & 22,34 & 3,13 & 7,77 & 0,56 & 1,44 & 8,64 & 0,52 \\
\hline & $40-60$ & $5 Y R 5 / 2$ & 32,88 & 35,82 & 28,11 & 3,19 & 7,86 & 0,52 & 0,45 & 0,26 & 0,31 \\
\hline & $60-80$ & $5 Y R 5 / 4$ & 16,90 & 38,97 & 39,49 & 4,65 & 7,88 & 0,47 & 1,84 & 2,45 & 0,45 \\
\hline
\end{tabular}

BW: Bound Water; OM: Organic matter; $\mathrm{CaCO}_{3}$ : Carbonate; $\mathcal{X}$ : magnetic susceptibility

The values obtained for the water contents at the level of the studied profiles present very low percentages and vary from $0.5 \%$ to $1.5 \%$, reflecting a well-drained soil. The organic matter contents are low in profiles 1 and 3 and higher in profile 2 . Their evolution in depth is marked by their increase at the average horizon $\mathrm{B}$ of profile two between 20 and $60 \mathrm{~cm}$. The predominance of coarse fractions facilitates good drainage of the soil, favoring organic matter oxidation.

Carbonate contents are globally very low in the profiles studied. They are marked by a significant increase from $0.21 \%$ to $6.89 \%$ in profile two between 60 and 120 
cm depth (Table 2). This variation is mainly related to the precipitation of carbonates in the upper horizons and the geochemical nature of the parent rock.

The magnetic susceptibility is low in the profiles studied. It varies from 0.15 . 10-3 to $0.9 .10-3$ SI on average. The magnetic susceptibility decreases with depth in profiles 1 and 2 (Table 2). Its distribution remains in general anti-correlative with that of the carbonates.

\section{Conclusion}

The present work has allowed us to diagnose the state of evolution of some soil profiles at the Oueds Nekôr and Ghiss watersheds level. The contrasting climate with a semi-arid atmosphere, the soft and diversified nature of the geological substratum, and the abrupt relief are factors that control the pedological evolution of the soils at the level of the studied watersheds. The sedimentological and geochemical analysis of the different soil profiles provides information on well-drained silty soil, not significantly evolved, relatively alkaline, and poor in organic matter and carbonates. The granulometric analysis shows that the profiles are stony at the surface in the well-drained and leached areas and conversely stony with depth in the more stable profiles. The low content of organic matter supported by the fine fractions is related to the low biological productivity of the soil, which is due to the degraded state of the vegetation cover. Overall, the low carbonate and magnetic susceptibility contents reflect a marl-schist to sandstone-marly nature of the soils sampled in the Oueds Nekôr and Ghiss watersheds.

\section{References}

1. D. Touhtouh, Y. Moujahid, M. El Faleh, R. EL Halimi, J. Mater. Environ. Sci, 6 (12) 3582-3593, (2015)

2. D. El Hafid, B. Akdim, European Scientific Journal, 14(5) 259-285, (2018)

3. HCEFLCD. Plan National d'Aménagement des Bassins Versants, Cadre stratégique. Maroc, (1996)

4. E. Roose, M. Sabir, A. Laouina. Marseille : IRD, (2010)

5. A. Lahlou, IAHS Publ, 194 (1990)

6. M. Moukhchane, S. Bouhlassa. A. Chalouan, Sécheresse 3(9), 227-232, (1998)

7. M. Moukhchane, Bull. Réseau Érosion, 21, 255-266, (2001).

8. A. Sadiki, S. Bouhlassa, J. Auajjar, A. Faleh, J. Macair, Bull. Inst. Sci., 26, 69-79, (2004)

9. S. Ibrahimi, Thèse de Doctorat National. Université Abdelmalek Essaadi. FST Tanger, (2005)

10. S. Ibrahimi, B. Damnati, O. Radakovitch, K. Hassouni, B. Simon, Revista de la Sociedad Geologica de Espana 18(3-4), 217-224, (2005)

11. B. Damnati, S. Ibrahimi, O. Benhardouze, O. Radakovitch. M. Moukhchane, Africa Geoscience Review, 17(3), 215-223, (2010)
12. S. Ed-Dakiri, Mémoire de Master, Université Abdelmalek Essaadi. FST Al-Hoceima, (2019)

13. H. Faiz. Mémoire de Master, Université Abdelmalek Essaadi. FST Al-Hoceima, (2019)

14. M. Moustakim. Thèse de Doctorat National Université Abdelmalek Essaadi. FST Tanger, (2021)

15. I. Etebaai. Habilitation Universitaire, Université Mohamed Premier. Faculté des Sciences. Oujda, (2021).

16. W.E.J. Dean, J Sed Petro, 44(1), 242-248, (1974) 